\title{
No government mouthpieces: Changes in the framing of the "migration crisis" in German news and infotainment media
}

Dennis Lichtenstein, Austrian Academy of Sciences / Alpen-Adria-University Klagenfurt, Institute for Comparative Media and Communication Studies (CMC), Austria

dennis.lichtenstein@oeaw.ac.at

\begin{abstract}
This study investigates the German media's framing of the 2015-2016 "migration crisis" and their support and criticism of the initial open-door policy. A standardized content analysis examines changes in media frames following the key event of assaults on New Year's Eve (NYE) 2015. It is analyzed how changes in coverage differed between public broadcasting news and infotainment formats (talk and satirical shows) and how they were related to governmental communication. The findings contradict ideas of a state-conforming and uniform coverage of the "migration crisis." Media coverage did not parallel the governmental switch from support for the open-door policy to ambivalence after the NYE incidents but challenged governmental communication with critical counter frames. Regarding support for the open-door policy, the news media showed some parallels to the government's frames; however, the infotainment media deviated in their frame agenda from the news media and thus contributed to diversity in media discourse.
\end{abstract}

\section{Keywords}

content analysis, crisis communication, infotainment, migration crisis, newscast, political satire, public broadcasts, talk show

\section{Introduction}

Since the late summer of 2015, migration has become an intensely politicized issue in almost every European society (Barlai, Fähnrich, Griessler, \& Rhomberg, 2017; Krzyżanowski, Triandafyllidou, \& Wodak, 2018). Extensive media coverage centered on refugees drowning in the Mediterranean Sea on their way to Europe and images of migration movements from Syria, Afghanistan, and Iraq to and throughout the European Union (EU).

During the so-called "migration crisis," ${ }^{1}$ Germany was the main destination country for asylum seekers (Juran \& Broer, 2017). In the German public discourse, the emotional and televised encounter of chancellor Angela Merkel (Christian Democratic Union) with the Palestinian

1 Migration was neither related to a significant economic breakdown nor to a similar strong social disruption as in the cases of war or natural disaster; hence, the quality of the situation as a crisis is contentious (Udris, 2019). refugee girl, Rem, in July 2015 and later the iconic image of the dead body of Aylan Kurdi at the Turkish shore invoked intense moral pressure on migration and asylum policies (Vollmer \& Karakayali, 2018). In this situation, Merkel's famous dictum from August 31, We Will Manage It, set a strong frame that emphasized the high influx of migrants as a societal challenge, addressed citizens as a collective $W e$, and motivated them for collective action in the name of humanity. The frame shaped governmental actions and subsequent public perceptions of events (Mushaben, 2017; Pries, 2020). In September 2015, more than 1000 refugees who were detained in Hungary marched out of Budapest toward the Austrian border. In agreement with Austrian officials, the German government decided to welcome refugees and allow them access to Germany instead of closing the borders.

At first, this open-door policy was broadly praised by the German public. In the later stages of events, however, justi- 
fying the decision became difficult. The public mood changed from solidarity and a welcome culture to warnings of a cultural clash, increased crime, and social problems, such as a housing shortage. Additionally, the German government shifted toward more restrictive policies, for instance, limiting the right to family reunification, extending the definition of safe countries of origin, and implementing measures for the faster deportation of irregular immigrants and rejected asylum seekers (Vollmer \& Karakayali, 2018). Within this process, several scholars identified the incidents on New Year's Eve (NYE) 2015 as a key event for changes in the discourse on the "migration crisis" and the public acceptance of migrants in Germany (Czymara \& Schmidt-Catran, 2017; Vollmer \& Karakayali, 2018). On NYE 2015, groups of men, most reportedly migrants from North Africa, attacked, robbed, and sexually harassed hundreds of women in Cologne and other German cities. While the German government was faced with accusations for a failed migration policy, the fact that, at first, German news media reported only gradually on these mass sexual assaults contributed to public media criticism and right-wing hostilities, first and foremost, against public service media (Bielicki, 2018).

This study investigates how the media's framing of the "migration crisis" changed following the incidents on NYE and to what extent German media supported or criticized the initial open-door policy before and after NYE. Unlike most previous works that have been limited to examinations of the news media's coverage of the "migration crisis," the content analysis presented in this study encompasses hard-fact oriented news and infotainment media formats that deal with a softening of news (Otto, Glogger, \& Boukes, 2017). Due to the trends of commercialization and digitalization, infotainment media formats - such as soft-news-focused newscasts, political talk shows, and satirical shows - have become an important part of today's pluralized media landscape (Farnsworth \& Lichter, 2003; Thussu, 2007). Although they are rarely studied in political communication science, they must be considered to contribute to public opinion formation, and, in their depiction, they might deviate from the news media (Wessler, 2018). The sample for the media material under study comprises newscasts, talk shows, and satirical shows from German public broadcasting. To assess how frames in media coverage are related to changes in government communication before and after NYE, the study on media content is complemented with an analysis of government communication.

The present article contributes to research on the media's role during the "migration crisis" and on media-politics relations. The findings from the content analysis shed light on how the incidents on NYE 2015 have shaped the media's depiction of the "migration crisis," how changes in media coverage were related to changes in governmental communication, and how news and infotainment formats differed in their framing when they supported or criticized the open-door policy. The findings contradict widespread suspicions against public service broadcasts for being biased in favor of migration and providing concordant and one-sided coverage (Brauck, Diez, Kühn, Müller, Nezik, \& Steinmetz, 2016). It is demonstrated that the media functioned critically toward the open-door policy and governmental communication before and after the NYE incidents. Since infotainment media deviated in their support and criticism of the open-door policy from the news media, they contributed to diversity in media discourse.

\section{The media's role in crisis communication}

Political communication scholars have intensively discussed the relation between policymaking and the media (e.g., Baugut \& Scherr, 2019). Although the media and politics are, to some extent, separate spheres with different agendas (Meyer, 2002; Roggeband \&Vliegenthart, 2007), the media's influence on the citizens' agenda and their perceptions of political issues are 
broadly acknowledged. For policymakers, they thus serve as an arena for frame competition as well as an indicator of the legitimacy of politics (Suchman, 1995; Wolfe, Jones, \& Baumgartner, 2013).

From a normative point of view, the media are tasked with contributing to democracy by providing reliable information and orientation, promoting social integration, and mobilizing individuals for societal objectives. The media should enable exchange and discussion between politicians and citizens and hold officials accountable (Blumler \& Coleman, 2015; McQuail, 2010). Regarding the media's normative role in media-policy relations, Christians, Glasser, McQuail, Nordenstreng and White (2009) differentiate between the main functions of criticism and cooperation. In their critical role, the media scrutinize political leadership. While alternative or critical media take a radical stance against power, mass media in the political mainstream instead function as watchdogs. They observe and comment on current processes and events and "bark" in the case of risks, threats, and dangers (Christians et al., 2009; Zaller, 2003). To fulfill their critical function, the media are asked to confront policymakers with at least one counter frame to the official governmental interpretation (Entman, 2004).

In contrast, in their cooperative role, the media do not place themselves in explicit antagonism with political power but instead support societal processes. When they give voice to civil society actors, promote participation, or focus on reason and context instead of conflict, for instance, the media can facilitate public deliberation, conflict resolution, and citizens' self-government (Lynch \& McGoldrick, 2005; Wessler, 2018). In some cases, they collaborate with the state, thereby contributing to the creation of public consensus for specific policies and policy reforms. While the media's cooperative role generally bears the risks of elite control and diminished diversity, in crisis situations, cooperation can prevent panicked reactions among citizens and help push the appropriate political crisis responses (Christians et al., 2009).
Empirical findings on media-policy relations are mixed. In a survey study, scholars found that political elites perceived the media to be influential for political careers and the policy agenda (Lengauer, Donges, \& Plassner, 2014). Comparing policy documents with media coverage, content analyses found a rather moderate, and not unidirectional, agenda-setting effect of media coverage on the political agenda (Vliegenthart \& Roggeband, 2007; Walgrave, Soroka, \& Nuytemans, 2008; Walgrave \& van Aelst, 2006). According to Dekker and Scholten (2017), the media's impact on the policy agenda is strongest when a variety of media outlets are consonant in their position on an issue and when this common position differs from the official policy agenda.

Most studies on the media-policy relation use the framing approach. A frame is "a central organizing idea or story line that provides meaning to an unfolding strip of events" (Gamson \& Modigliani, 1987, p. 143). Frames emphasize a particular problem definition, its underlying causes, and its consequences. They thus promote a certain interpretation that contributes to the persuasiveness of arguments and suggests a positive or negative evaluation of the issue at stake (Entman, 1993). Policymakers use frames strategically. They are likely to receive support for their crisis politics in media discourses when they adopt coherent and mutually reinforcing frames. To present their actions as "desirable, proper, or appropriate within some socially constructed system of norms, values, beliefs and definitions" (Suchman, 1995, p. 574), policymakers use frames that resonate with a society's culture, apply to common values (e.g., democracy and peace), and strengthen support for the proposed crisis response as a question of morality (Entman, 2004; Olsson, Söderlund, \& Falkenheimer, 2015).

According to Bennett's (1990) indexing thesis, the media tend to accept political leaders' frames as long as top-level officials present a unified front, while counter frames may become more prevalent in cases of open controversy about the issue at an elite level. Empirical studies on media 
content have found that counter frames are limited, but not marginalized, in crisis situations, and the elite dominance of media frames is reduced over time (Bennett, Lawrence, \& Livingston, 2006; Glazier \& Boydstun, 2012; Hayes \& Guardino, 2010). While the media have been found to exert efforts that demand accountability from the government, Bytzek's (2005) analysis of the German media's coverage of German engagement in the Kosovo crisis demonstrated that criticism by the media was basically related to specific actions and measures but did not challenge the legitimacy of the government's policy. In addition, the media's tendency to domesticate (global) crisis events by stressing the relevance for their own country and focusing on national actors (Eide \& Ytterstad, 2011) can lead to parallels to official communications. Conversely, in cases of domestic crises, a broad range of midlevel sources provides journalists with information. Unlike foreign policy crises, media coverage of domestic events has thus been found to substantially diverge from governmental communication (Allen \& Blinder, 2018).

\section{Framing migration in media and policy discourses}

Migration policy is well known for being a highly contested policy domain (Bonjour \& Schrover, 2015; Vliegenthart \& Roggeband, 2007). In political and media debates, competing frames portray migrants as victims, intruders, or economic refugees and deal, for instance, with criminality, illegal migration, and Islam as threats as well as long-term economic risks and prospects (e.g., Benson, 2013; Greussing \& Boomgaarden, 2017; Helbling, 2014; Horsti, 2007; Ihlen \& Thorbjørnsrud, 2014; Roggeband \& Vliegenthart, 2007; van Gorp, 2005). Dekker and Scholten (2017) summarized the variety of frames identified in different studies into four master frames: 1) human interest, 2) migration as a threat, 3) economy, and 4) migration as a governance challenge.

Previous studies have found conflicting interactions and mutual influences be- tween migration-related frames on policy and the media agenda (Dekker \& Scholten, 2017; Ihlen \& Thorbjørnsrud, 2014; Vliegenthart \& Roggeband, 2007; Walgrave et al., 2008). In line with the indexing thesis, debates or reforms in the policy arena trigger media coverage and provide orientation for the media's framing of migration (Bonjour \& Schrover, 2015; Vliegenthart \& Walgrave, 2011). Klocker and Dunn (2003) found that the media followed the government's negative tenor toward asylum seekers. However, the media can shape migration policies by stressing frames that are not dominant on the policy agenda. As some authors have argued, the coverage of migration in terms of a crisis and the presentation of migrants as intruders can push restrictive migration policies or hinder reforms for liberalization (Suro, 2009; Vukov, 2003). This is different when migration is predominantly framed as a governance challenge on the policy agenda, and the media simultaneously deploy the human-interest frame by focusing on life stories and individual tragedy. This constellation leads to a highly emotionally loaded "David versus Goliath" or "human against the system" debate, which can pressure political leaders to make exceptions in singular cases or produce a more general policy turn toward liberalization (Bonjour \& Schrover, 2015; Dekker \& Scholten, 2017; Horsti, 2007; Ihlen \& Thorbjørnsrud, 2014).

Regarding the German discourse on the "migration crisis," studies revealed an overall consonance between the different news media's coverage that was seen as largely consistent with the policy agenda (Greck, 2018; Haller, 2017; Hemmelmann \& Wegner, 2016; Maurer, Jost, Haßler, \& Kruschinski, 2019). In the news media, the "migration crisis" was initially depicted as a humanitarian catastrophe that required immediate action. Even though the media were concerned with sociocultural challenges and the limited capacities to deal with the high influx of refugees, according to Haller (2017), the notion of German welcome culture was actively supported by journalists. In a more nuanced analysis, Maurer et al. (2019) demonstrated that 
print and TV news media covered migrants in a positive tonality when individual and human-interest aspects were covered. Meanwhile, negative tonality was related to more abstract coverage dealing with migration as a risk and danger. Even though media coverage was found to be accurate in light of official statistics (Maurer et al., 2019), in the general picture, the media took a rather supportive position toward governmental communication and policy decisions.

Several authors, however, have identified the incidents on NYE 2015 as a key event in German media discourse. Accordingly, the media began to strongly emphasize threats to security and cultural homogeneity in Germany (Haller, 2017). In the media representation of migrants, NYE marked a shift from predominant attention toward vulnerable individuals and groups (children, female migrants, families) deserving help and compassion to young men who were perceived as a societal danger and the cultural "other" (Vollmer \& Karakayali, 2018). Consistent with this previous work, it can therefore be expected that after the NYE events, the German media deployed stronger criticism of the open-door policy in their framing of the "migration crisis" compared to the time before. Therefore, I propose the following hypothesis:

$\mathrm{H} 1$ : In the media's framing of the "migration crisis," criticism of the opendoor policy increased after the NYE events compared to the time before.

Existing studies have analyzed the content of hard-fact oriented news media, whereas research on infotainment media formats covering the "migration crisis" remains scarce. Contrary to quality newspapers and public broadcasting news that routinely select, structure, and comment on information from the daily stream of events, commercial and highly soft-newsfocused newscasts, political talk shows, and satirical shows combine information with an entertaining style of presentation. In their coverage of the "migration crisis," they are expected to have deviated from the news media in two significant ways: the extent to which they support or criticize the government's crisis management (and the open-door policy in particular), and the frames on which they base their support and criticism.

For example, political talk shows are a forum for discussing conflicting frames. As the selection of guests follows the principle of "confrontainment" (Klemm, 2015), or entertainment by confrontation, talk shows frequently include critical voices that challenge the government's policies. Other infotainment formats are even more likely to fulfill the media's critical function. Most prominently, satirical shows challenge established perspectives in current political and societal debates with a counter-narrative meant to criticize political leaders and traditional media discourses (McClennen \& Maisel, 2014). According to studies on the depiction of the Ukraine crisis (Lichtenstein \& Koerth, 2020) and the "migration crisis" (Nitsch \& Lichtenstein, 2019), criticism of governmental policies is especially strong in satirical shows when the news media tend to support the government's position. In the case of the "migration crisis," the news media are expected to have supported the open-door policy before NYE and shifted toward criticism in the time after, when the government also shifted toward more restrictive policies. Therefore, the opposite is hypothesized for infotainment formats:

H2: Compared to the news media, infotainment formats deployed a lower share of frames supporting the opendoor policy before the incidents on NYE and a higher share of supportive frames in the time after.

In more detail, news and infotainment formats are expected to have differed in the frames that they deployed when they supported and criticized the government's open-door policy during the "migration crisis." Based on Bennett's (1990) indexing thesis, the news media are likely to adapt to government's frames in their support for the open-door policy before the incidents on NYE. Infotainment formats, how- 
ever, are said to focus less on policy issues while placing a stronger emphasis on human interest, conflict, and the emotional aspects of political issues (Baum, 2007; Reinemann, Stanyer, Scherr, \& Legnante, 2012). They are expected to have framed support for the open-door policy as against tendencies toward populism and xenophobia. Similarly, in their criticism of the open-door policy, infotainment formats might have focused less on policy criticism than on the government's performance as a crisis manager. Conversely, the news media are expected to have given policy criticism on the open-door policy. Therefore, in addition to H2, I propose the following two hypotheses:

H3: In their support for the open-door policy before the incidents on NYE, infotainment media formats criticized populism and xenophobia more frequently than the news media.

H4: In their criticism of the open-door policy, the news media used policy-related frames more frequently compared to infotainment media formats.

\section{Method}

To assess how news and infotainment media formats supported or criticized the open-door policy in their framing of the "migration crisis," a systematic content analysis of media coverage in Germany was conducted. Additionally, to consider changes in governmental communication before and after the NYE incidents, the media analysis was supplemented with an analysis of government communication. The study examines and compares issue-specific frames. In contrast to studies on generic frames (which are more abstract categories that can be analyzed in relation to different topics), the analysis of issue-specific frames enables the exploration of the specific story lines about the "migration crisis" presented in news and infotainment media formats and governmental communication (de Vreese, 2005).

\subsection{Material under study}

The analysis of government communication was based on press releases, government statements, and transcripts from federal press conferences. The media sample consisted of a daily TV newscast and the infotainment formats of political talk shows and satirical shows. Due to the plurality of existing media outlets, the sample is not representative of the German media landscape. For instance, it lacks conservative and liberal quality press, weekly magazines, the regional press, tabloids, and online news formats on YouTube. The sample, however, enables a comparison between prominent news and infotainment formats and extends the spectra of media formats that are usually analyzed in crisis discourses.

The newscast Tagesschau was selected because of its high reputation and broad reach (see Appendix, Table A1). The analysis of political talk shows referred to two of the broadest-reaching programs in Germany, Anne Will and Maybrit Illner, both of which are broadcast weekly. Three satirical shows were chosen, namely, the news satire show heute-show, the late-night show Neo Magazin Royale (both broadcast weekly), and Die Anstalt (broadcast once a month), which follows the tradition of cabaret theater. All the media selected are broadcast by German public service stations.

The analyzed period started in September 2015 after Merkel's dictum, We Can Manage It, and her decision to implement the open-door policy, and it ended in April 2016 (Table 1). This timeframe enables the differentiation between two periods that are distinguished by the key event of NYE 2015, which was related to a discursive shift in public communication according to prior research (Haller, 2017; Hemmelmann \& Wegner, 2016; Maurer et al., 2019). Due to the sample's heterogeneity, the exact sampling procedure varied among the different kinds of material under study. Government communication and the satirical shows entailed few frames per unit and were thus selected from over the whole period. Relevant governmental communication pieces were collected on the German government's official website 
Table 1: Material under study

\begin{tabular}{|c|c|c|c|c|}
\hline & $\begin{array}{c}\text { Government } \\
\text { communication }\end{array}$ & Newscast & Talk shows & Satirical shows \\
\hline \multicolumn{5}{|l|}{ Sep 1-Dec 31, 2015} \\
\hline Press releases/broadcasts & 44 & 20 & 5 & 32 \\
\hline Relevant thematic segments & 0 & 68 & 0 & 80 \\
\hline Frames & 62 & 255 & 266 & 251 \\
\hline \multicolumn{5}{|l|}{ Jan 1-Apr 30, 2016} \\
\hline Press releases / broadcasts & 21 & 20 & 6 & 25 \\
\hline Relevant thematic segments & 0 & 52 & 0 & 62 \\
\hline Frames & 43 & 179 & 223 & 180 \\
\hline
\end{tabular}

(https://www.bundesregierung.de/) and identified by a keyword search using the terms Flucht, Flüchtling*, and Migration. The coding referred to a random sample of 65 relevant government communication pieces. For the satirical shows, all 57 shows that addressed the "migration crisis" as the main topic in at least one thematic segment were selected. The relevant shows and segments were identified by using data from a previous project on political satire (Nitsch \& Lichtenstein, 2019).

The investigation period for the newscast and talk shows was limited to 31 days, starting from the day after the key event (period 1: the open-door policy implementation on September 5, 2015; period 2: after NYE 2015). Within this time frame, the coding referred to a random sample of 20 broadcasts per period for Tagesschau. Only crisis-relevant thematic segments of the newscast were coded. These were identified by the broadcast description on the website Tagesschau.de/archive. For talk shows, all broadcasts that referred to the "migration crisis" in their title or announcement in the defined time frames were selected (11 in total). Since talk shows are monothematic, coding referred to the complete shows.

\subsection{Analysis and measures}

In government communication and media material, the coding unit was the single frame of the "migration crisis" as occurring in a sentence or some connective sentences uttered by a specific public speaker. A frame establishes a specific understanding of the situation, for example, as a humanitarian crisis in Arab countries or as a political crisis in Germany. The coding followed a standardized procedure using strictly defined categories to classify demanding interpretations (e.g., Gamson \& Modigliani, 1989; Simon \& Xenos, 2000). The catalog of frames stemmed from a qualitative pre-study of a selection of the material following Mayring's (2014) summarizing approach. In the pre-study, 10 frames were identified and differentiated inductively and structured into three frame groups according to their main focus on the crisis (Gamson \& Modigliani, 1989). In line with Entman's (1993) popular definition of a frame consisting of four elements, the frames of the "migration crisis" were coded as a specific combination of a problem definition, causal interpretation, moral evaluation, and treatment recommendation. In the problem definition, frames deal with a global, European, or German perspective, which was decisive for the systematization of frames into frame groups.

Ten frames and three frame groups were differentiated. The frames in the first group address the "migration crisis" as a crisis in Arab countries and highlight the following: 1) the reasons for migration, such as terrorism, war, and poverty, or 2) the Western responsibility for economic problems and political conflicts in the Arab world. Both frames lead to the treatment recommendation to receive refugees for humanitarian reasons. The frames in the second group refer to a European crisis. They stress the following: 3 ) the conflicts between EU countries that undermine a united EU crisis management, 
or 4) the humanitarian or administrative problems inside EU countries arising from the influx of migrants. These frames tend to blame individual EU countries for the crisis. At the same time, they appeal for a greater commitment from the EU and a coordinated EU asylum policy in their treatment recommendation.

The third group of frames is more concerned with the political and social situation in Germany. These frames provide support for, or criticism of the open-door policy. The supportive frames focus on the following: 5) societal challenges in integration and cohabitation, 6) motivational appeals for welcoming the refugees, and 7) problematizing the increase in populism and radicalism in German society. Frames that criticize the open-door policy are policy-related when they highlight 8) deficits in the German asylum law combined with appeals for restrictions to limit migration. Other critical frames focus more on the government's performance as a crisis manager and emphasize the following: 9) the open-door policy as political mismanagement and 10) administrative problems with the handling of the influx of migrants.

A frame was coded when at least two frame elements were addressed by a public speaker. In the press material, the broadcasts, and the speakers' statements within the broadcasts, all identified frames were coded. One frame could be coded several times in one broadcast if addressed by different speakers or by the same speaker in different statements. Coding was conducted by four coders who were trained for six weeks. The reliability coefficient for the key variables showed a sufficient level (for the frames: Krippendorff's $\alpha=.76$, and for public speakers: $\alpha=.83$ ). The reliability of the frames differed slightly among the materials under study (government communication: Krippendorff's $\alpha=.77$, newscast: $\alpha=.78$, talk shows: $\alpha=.76$, and satirical shows $\alpha=.74)$. Coder training and reliability tests were based on the coding of 40 randomly selected broadcast segments and 10 pieces of government communication releases, all of which included a total of 164 frames.

\section{Results}

A total of 1459 frames were coded. German governmental communication consisted of officials' frames only $(n=105)$. Newscast frames $(n=434)$ stemmed from the newscast's editorial staff $(37.6 \%)$ and external sources, who were most frequently representatives from the German government (17.5\%) and non-governmental politicians (25.8\%). In the talk shows, most frames $(n=489)$ were sponsored by non-governmental politicians $(41.2 \%)$, civil society actors $(16.8 \%)$, governmental politicians $(11 \%)$, and journalists $(9.6 \%)$. In the satirical shows, all coded frames on the "migration crisis" stemmed from the editorial staff members of the shows.

The findings revealed that before and after the incidents on NYE 2015, all the analyzed formats paralleled government communication by depicting the "migration crisis" as a crisis in Germany predominantly and as a European crisis secondarily (Table 2). The strong focus on Germany can be explained by political efforts to recognize problems that directly affected German citizens, the media indexing the policy debate (Bennett, 1990), and the media's tendency to domesticate global issues (Eide \& Ytterstad, 2011). However, in doing so, the media tended to underemphasize the global dimension of the problem. This included Western responsibilities for economic problems and political conflicts in the countries of origin as well as the reasons for migration, which contributed to legitimizing the influx of migrants on humanitarian grounds. Domestication can also convey the misleading idea that the crisis could be solved in and by Germany.

For the frame group European crisis, governmental communication and media coverage highlighted the crisis of the EU more often than the problems in individual EU countries. The frame Crisis of the EU stressed the need for a coordinated EU asylum policy and mainly attributed responsibility to the EU. From the German government's perspective, the frame allowed it to present itself as a European crisis manager and to externalize blame for the tense situation in Germany to other EU countries 
Table 2: $\quad$ Frame groups in government communication and media coverage (in \%)

\begin{tabular}{|c|c|c|c|c|c|c|c|c|}
\hline & \multicolumn{2}{|c|}{ Government communication } & \multicolumn{2}{|c|}{ Newscast } & \multicolumn{2}{|c|}{ Talk shows } & \multicolumn{2}{|c|}{ Satirical shows } \\
\hline & $\begin{array}{c}\text { Before NYE } \\
(n=62)\end{array}$ & $\begin{array}{l}\text { After NYE } \\
(n=43)\end{array}$ & $\begin{array}{l}\text { Before NYE } \\
(n=255)\end{array}$ & $\begin{array}{l}\text { After NYE } \\
(n=179)\end{array}$ & \begin{tabular}{|c} 
Before NYE \\
$(n=266)$
\end{tabular} & $\begin{array}{l}\text { After NYE } \\
(n=223)\end{array}$ & \begin{tabular}{|l} 
Before NYE \\
$(n=251)$
\end{tabular} & $\begin{array}{l}\text { After NYE } \\
(n=180)\end{array}$ \\
\hline $\begin{array}{l}\text { Frame group: } \\
\text { Arab crisis }\end{array}$ & 10 & 7 & 14 & 10 & 11 & 10 & 9 & 4 \\
\hline $\begin{array}{l}\text { Western } \\
\text { responsibility }\end{array}$ & 7 & 0 & 9 & 3 & 3 & 5 & 9 & 4 \\
\hline $\begin{array}{l}\text { Reasons for } \\
\text { migration }\end{array}$ & 3 & 7 & 6 & 7 & 8 & 5 & 0 & 0 \\
\hline $\begin{array}{l}\text { Frame group: } \\
\text { European crisis }\end{array}$ & 29 & 40 & 27 & 21 & 25 & 21 & 22 & 23 \\
\hline Crisis of the EU & 18 & 26 & 18 & 18 & 23 & 19 & 17 & 22 \\
\hline $\begin{array}{l}\text { EU country } \\
\text { in crisis }\end{array}$ & 11 & 14 & 9 & 2 & 3 & 2 & 4 & 2 \\
\hline $\begin{array}{l}\text { Frame group: } \\
\text { Crisis in Germany }\end{array}$ & 61 & 54 & 59 & 70 & 64 & 70 & 70 & 73 \\
\hline
\end{tabular}

Note: Differences in the sum are due to rounding. For the frame groups Arab crisis and European crisis, the table also discloses the values for the single frames.

Figure 1: Changes in support for and criticism of the open-door policy after NYE 2015

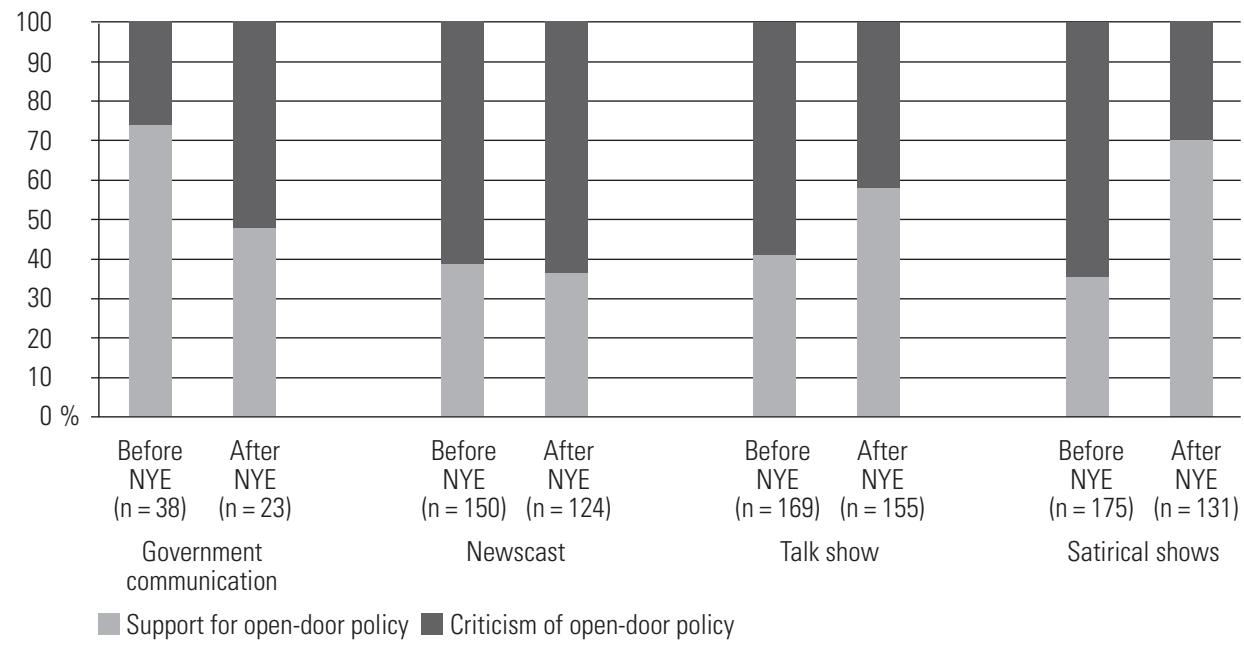

Note: Percentages for support for and criticism of the open-door policy result from the total of supportive frames (Integration and Cohabitation, We Will Manage It, Populism and Radicalism) and critical frames (German Asylum Policy, Political Mismanagement, Administrative Problems).

(such as Hungary and Poland) that prevented a common EU asylum policy. After NYE, disruptive events and decreasing public acceptance of the high migration influx put pressure on the German government to externalize the blame. Thus, the government placed an increased emphasis on the European dimension of the issue, which was not paralleled to the same extent in media discourse.

Within the frame group Crisis in Germany, differences in support for and criticism of the open-door policy (as expressed in the respective framing of the "migration crisis") became obvious between the periods before and after the NYE incidents (Figure 1). Consistent with policy chang- 
es, the German government initially supported the open-door policy but was more ambivalent in the time after NYE $\left[\chi^{2}(1\right.$, $N=61)=4.16, p=.042]$.

In contrast to the expectation in hypothesis 1 , the media did not parallel governmental communication and showed no increased criticism after the NYE events compared to the time before. In the period before the NYE events, the analyzed media formats deployed frames that were in line with government communication and supported the open-door policy to the extent of $35 \%$ to $41 \%$ only. The media thus already had a stronger focus on critical counter frames before NYE, and media criticism of the open-door policy did not increase in the time after. While the newscast Tagesschau framed the "migration crisis" in a similar critical way during both periods under study, the share of support for the open-door policy increased significantly in the talk shows [58.1\%; $\chi^{2}(1$, $N=324)=9.61, p=.002$ ] and satirical shows $\left[70.2 \% ; \chi^{2}(1, N=306)=36.29, p=.001\right]$ and now outweighed criticism. This finding contrasts with previous research that found strong media support for a welcome culture (Haller, 2017). Consonance in media criticism on the open-door policy, however, must be considered to have influenced the political agenda (Dekker \& Scholten, 2017). Pressure from media coverage thus explains, to some extent, the switch in governmental communication from support for the open-door policy to ambivalence.

Hypothesis 2 is partly confirmed. This hypothesis proposes that, compared to news media, infotainment formats were more critical of the open-door policy before NYE and more supportive in the time after. However, the newscast and infotainment formats showed no significant difference in the extent of their support or criticism for the open-door policy in the period before NYE. ${ }^{2}$ After NYE (and in accordance with $\mathrm{H} 2$ ), frames that supported the open-

2 The critical frames were addressed significantly more frequently than the supportive frames in the newscast $\left[\chi^{2}(1, N=150)=7.71\right.$, $p=.006]$, the talk shows $\left[\chi^{2}(1, N=169)=5.69\right.$, $p=.017]$, and the satirical shows $\left[\chi^{2}(1\right.$, $N=175)=14.86, p=.001]$. door policy were more common in the infotainment media formats of talk shows [59\%; $\left.\chi^{2}(1, N=279)=13.08, p=.001\right]$ and satirical shows $\left[70 \% ; \chi^{2}(1, N=255)=29.51\right.$, $p=.001]$ compared to traditional newscasts (36\%). Satirical shows also deployed a significantly higher share of supporting frames compared to talk shows $\left[\chi^{2}(1\right.$, $N=286)=4.54, p=.033$ ]. Satirical shows played their critical role in opposing governmental communication in both periods under study and by opposing news media discourse after the NYE events. In addition, the higher share of frames supporting the open-door policy after NYE demonstrates that the soft-news focus of infotainment is not related to stronger criticism in infotainment formats.

Differences in the framing of the "migration crisis" between the news and infotainment media and their relationship to governmental communication varied between the periods under study. Before NYE, the government's communication aligned with the aim to legitimate the open-door policy (Table 3). Using the frame Integration and Cohabitation, the government met the German citizens' concerns about the effects of migration on their daily lives. The frame We Will Manage It aimed at motivating citizens and claimed that German politics and society could successfully solve the crisis together. In contrast, the frame Populism and Radicalism criticized and warned of xenophobia and populism.

As anticipated by H3, the newscast, when expressing support for the opendoor policy, tended to follow the government's framing of the "migration crisis." Contrary to expectations, the same also applied to the infotainment format of talk shows. Both formats ranked the government's main frame Integration and Cohabitation as primary and the frame We Will Manage It as secondary. They reported on volunteers who were actively supporting the influx of migrants. The satirical shows, however, addressed the governmental frames to a lesser extent compared to the newscast and talk shows. ${ }^{3}$ Instead, satir-

3 For the frame Integration and Cohabitation, the difference between satirical shows and talk shows $\left[\chi^{2}(1, N=344)=4.57, p=.033\right]$ 
Table 3: $\quad$ Framing the migration crisis as a German crisis in government communication and the media, Sep 1-Dec 31, 2015 (in \%)

\begin{tabular}{lcccr}
\hline & $\begin{array}{c}\text { Government } \\
\text { communication }(\mathrm{n}=38)\end{array}$ & $\begin{array}{c}\text { Newscast } \\
(\mathrm{n}=150)\end{array}$ & $\begin{array}{c}\text { Talk shows } \\
(\mathrm{n}=169)\end{array}$ & $\begin{array}{r}\text { Satirical shows } \\
(\mathrm{n}=175)\end{array}$ \\
\hline Integration and Cohabitation & 42 & 15 & 18 & 10 \\
We Will Manage It & 16 & 14 & 12 & 6 \\
Populism and Radicalism & 16 & 9 & 10 & 19 \\
German Asylum Policy & 16 & 20 & 11 & 3 \\
Political Mismanagement & 0 & 25 & 33 & 9 \\
Administrative Problems & 1 & 17 & 16 & 53 \\
\hline
\end{tabular}

Note: Differences in the sum are due to rounding.

ical shows deployed the frame Populism and Radicalism, criticizing xenophobic attitudes in society more frequently than did the newscast $\left[\chi^{2}(1, N=325)=6.54, p=.011\right]$ and talk shows $\left[\chi^{2} \quad(1, N=344)=5.98\right.$, $p=.014]$. In adopting this frame, satirical shows took a moral stance against growing xenophobia and right-wing violence. Hypothesis 3, which proposes that the infotainment formats criticized populism and xenophobia more frequently than did the news media, is thus confirmed from the findings on the difference between the newscast and satirical shows.

Regarding criticism of the open-door policy, policy-related criticism (expressed by the frame German Asylum Policy) was more frequently found in the analyzed newscast than in the infotainment formats. In contrast, criticism of the government's general performance as a crisis manager (expressed by the frames Political Mismanagement and Administrative Problems) was more frequently found in the infotainment media formats. This difference proved to be significant between the newscast and talk shows $\left[\chi^{2}(1, N=192)=5.45\right.$, $p=.020$ ] as well as between the newscast and satirical shows $\left[\chi^{2}(1, N=205)=28.45\right.$, $p=.001]$ and thus confirms hypothesis 4 . However, Political Mismanagement, which criticized the government's crisis management and challenged its reputation, was the most frequently stressed frame in both

proved significant. Regarding the lower employment of the frame We Will Manage It in the satirical shows, the difference proved to be significant in comparison to the newscast $\left[\chi^{2}(1, N=325)=6.43, p=.011\right]$ and the talk shows $\left[\chi^{2}(1, N=344)=4.72, p=.030\right]$. the newscast and talk shows. In talk shows, this frame included, for instance, warnings of symbolic effects because the open-door policy could be perceived as an invitation to people in Arab countries to migrate to Germany. In contrast to the newscast and talk shows, the satirical shows treated the frames German Asylum Policy and Political Mismanagement only as side aspects of the debate and, instead, more dominantly focused on Administrative Problems. ${ }^{4}$ In doing so, they resisted criticizing the principle of the open-door policy but highlighted fixable bureaucratic problems.

After the NYE incidents, government communication switched from promoting a welcoming of refugees to a framing that was more suitable for legitimizing restrictions in migration policy (Table 4 ). Therefore, the government deployed the frames German Asylum Policy and Integration and Cohabitation. The combination of these frames resulted in promising restrictive asylum policies as a reaction to societal problems, while simultaneously appealing to peaceful cohabitation. This indicated an attempt to calm the debate by promising a decrease in the migration influx.

Regarding support for the open-door policy, all the analyzed media formats, however, paralleled the government communication by giving much attention to the frame Integration and Cohabitation. While the frame We Will Manage It lost weight in government communication and the an-

4 The satirical shows used the frame $A d$ ministrative Problems significantly more frequently than the newscast $\left[\chi^{2} \quad(1\right.$, $\mathrm{N}=325)=46.47, p=.001]$ and the talk shows $\left[\chi^{2}(1, \mathrm{~N}=344)=52.28, p=.001\right]$. 
Table 4: $\quad$ Framing the migration crisis as a German crisis in government communication and the media, Jan 1-Apr 30, 2016 (in \%)

\begin{tabular}{lcccr}
\hline & $\begin{array}{c}\text { Government } \\
\text { communication( } \mathrm{n}=23)\end{array}$ & $\begin{array}{c}\text { Newscast } \\
(\mathrm{n}=124)\end{array}$ & $\begin{array}{c}\text { Talk shows } \\
(\mathrm{n}=155)\end{array}$ & $\begin{array}{r}\text { Satirical shows } \\
(\mathrm{n}=131)\end{array}$ \\
\hline Integration and Cohabitation & 35 & 22 & 33 & 32 \\
We Will Manage It & 9 & 7 & 7 & 0 \\
Populism and Radicalism & 4 & 7 & 19 & 38 \\
German Asylum Policy & 39 & 13 & 20 & 1 \\
Political Mismanagement & 0 & 35 & 17 & 9 \\
Administrative Problems & 13 & 16 & & 20 \\
\hline
\end{tabular}

Note: Differences in the sum are due to rounding.

alyzed media formats, the satirical shows paid particularly strong attention to the frame Populism and Radicalism, which was found significantly less frequently in the newscast $\left[\chi^{2}(1, N=154)=10.10\right.$, $p=.001]$. The satirical shows thereby acted to criticize the xenophobic tendencies among the German population. To a lesser extent, the talk shows also pointed out the social divide on the issue of migration, referring to the frame Populism and Radicalism.

However, the second government frame, German Asylum Policy, which promised legislative restrictions to liberal migration policy, was deployed to a rather low extent in all formats. As expected in hypothesis 4 , this policy-related criticism was more frequently deployed in the newscast compared to the infotainment media formats, which had a stronger focus on criticism of the government's performance as a crisis manager. The difference is significant in the comparison between the newscast and satirical shows $\left[\chi^{2}(1, N=118)=6.63\right.$, $p=.010]$, but not between the newscast and talk shows. Therefore, hypothesis 4 is only partially confirmed. The frame Political Mismanagement ranked first in the newscast and second in the talk shows. This frame, however, registered a comparably low level in the satirical shows, where $A d$ ministrative Problems remained the most frequently used counter frame. Consistent with a previous study (Nitsch \& Lichtenstein, 2019), the satirical shows thus also resisted denouncing the open-door policy as political mismanagement in the time after the NYE events.

\section{Discussion and conclusion}

The comparison between the framing of the "migration crisis" before and after the incidents on NYE revealed changes in governmental communication. Still, it provided little evidence for the interpretation of NYE as a turning point in the media's evaluation of the open-door policy. This can be stated even though previous studies found a decrease of support for migration and growing attention toward less vulnerable groups of migrants in the media following the NYE events (Haller, 2017; Vollmer \& Karakayali, 2018).

The findings also contradict claims that suspected the media of a state-conforming coverage of the "migration crisis." Compared to governmental communication, the media followed a separate frame agenda that to a large extent criticized the open-door policy and exercised pressure on governmental communication. The strong presence of counter frames that criticized the open-door policy can be explained by the media's focus on the "migration crisis" as a domestic crisis and not a foreign one. Thus, journalists were likely to include midlevel sources instead of relying only on governmental frames (Allen \& Blinder, 2018). In addition, the governmental frames were contrasted by visible administrative problems. This finding of strong media criticism, particularly before the NYE events, is well in line with research on the media coverage of migration (Roggeband \& Vliegenthart, 2007; van Gorp, 2005; Vukov, 2003), although it contradicts to some extent prior research on the crisis discourse on migration in 
Germany (Haller, 2017; Hemmelmann \& Wegner, 2016). This can be explained by methodological considerations. Unlike previous analyses on keywords and the overall tonality of coverage, this study provides a more in-depth systematic analysis, taking all frames deployed in a media piece into account.

For the comparison between media formats, this study showed that infotainment formats contributed to media discourse on the "migration crisis" with a frame agenda that deviated from the newscast. While this contradicts the idea of uniform media coverage in public broadcasting, the findings provide little support for the assumption that news and infotainment media formats systematically differed in their cooperative or critical role with respect to the state. In particular, the newscast Tagesschau did not prove to fulfill the expected cooperative function but demonstrated criticism of the opendoor policy before the incidents on NYE. In line with the indexing thesis (Bennett, 1990), this can be explained by a lack of elite consensus in politics, as parties were divided about crisis management, and thus, provided critical orientation.

As expected, news and infotainment formats were found to deviate in the way they criticized the open-door policy. Compared to the infotainment media formats, the newscast emphasized policy-related criticism more frequently. This is in line with a stronger focus on hard news, while infotainment media have a stronger emphasis on conflict, emotion, and human interest (Baum, 2007; Reinemann et al., 2012), leading them to put a spotlight on the government's general performance as a crisis manager. In doing so, the talk shows constantly presented competing frames and highlighted conflict, with a strong focus on political mismanagement. Thus, satirical shows took a critical stance against governmental communication but not against the open-door policy - and tended to oppose central frames in the newscast and, to some extent, in the talk shows.

This study extended the spectra of media that are usually analyzed in research on media-politics relations. Nevertheless, the sample showed only a non-representative portion of the German media system, and most importantly, the plurality of online media was not represented. A further limitation concerns the selected time frame, which is only relevant to two major events in the "migration crisis" from a German perspective: the welcoming of refugees and the incidents on NYE. Both events dominated the crisis discourse for long periods. However, how other events, such as terrorist attacks or violent incidents against migrants, were related to even slight changes in the framing of the "migration crisis" was not examined. For such a detailed analysis of changes in the use of frames over time, a more extensive data collection would be required.

The analyzed material was selected for two distinct periods divided by the key event of NYE 2015. However, the material covered the periods under comparison differently, varying between 30 days and both periods as a whole. This methodological ambiguity was employed to guarantee a sufficient number of frames for each investigation unit. However, the overall design allowed for a comparison of media formats and the media and policy agenda, but not analysis of causalities between them. Hence, further research should focus more on the interactions between government and media communication. Future studies should also include strategic communication from civil society organizations and other interest groups, such as Pro Asyl and Pegida.

Despite these limitations, the findings revealed that news and infotainment formats created a critical media environment in which the German government did not achieve support for its open-door policy. The media acted in line with their normative task to scrutinize politics with counter frames and to hold the government accountable (Christians et al., 2009; Entman, 2004). As all the analyzed media formats were from public broadcasting, this contradicts claims that public broadcasting serves as mere conformist mouthpieces of the state. In addition, the findings showed that different infotainment media formats 
displayed their own accounts of crisis discourses and political events. This calls for further discussions regarding a more systematic differentiation of the impacts of infotainment media formats on public opinion formation in an increasingly complex media environment.

\section{Acknowledgement}

I especially thank my colleagues Birte Fähnrich and Cordula Nitsch and our former student assistant Julia Tauss who all were involved in the coding.

\section{Conflict of interest}

The author declares no conflict of interests.

\section{References}

Allen, W. L., \& Blinder, S. (2018). Media independence through routine press-state relations: Immigration and government statistics in the British press. The International Journal of Press/ Politics, 23(2), 202-226. https://doi. org/10.1177/1940161218771897

Barlai, M., Fähnrich, B., Griessler, C., \& Rhomberg, M. (Eds.) (2017). The migrant crisis: European perspectives and national discourses. Münster, Germany: LIT.

Baugut, P., \& Scherr, S. (2019). Should the media be more or less powerful in politics? Individual and contextual explanations for politicians and journalists. Political Communication, 36(1), 127-148. https:// doi.org/10.1080/10584609.2018.1517844

Baum, M. A. (2007). Soft news and foreign policy: How expanding the audience changes the policies. Japanese Journal of Political Science, 8(1), 115-145. https://doi. org/10.1017/S1468109907002502

Bennett, W. L. (1990). Toward a theory of press-state relations. Journal of Communication, 40(2), 103-127. https://doi. org/10.1111/j.1460-2466.1990.tb02265.x

Bennett, W. L., Lawrence, R. G., \& Livingston, S. (2006). None dare call it torture: Indexing and the limits of press independence in the Abu Ghraib scandal. Journal of Communication, 56(3), 467-485. https://doi. org/10.1111/j.1460-2466.2006.00296.x

Benson, R. (2013). Shaping immigration news: A French-American comparison. Cambridge, MA: Cambridge University Press.

Bielicki, J. (2018). Cologne's New Year's Eve sexual assaults. The turning point in German media coverage. In G. Dell'Orto \& I. Wetzstein (Eds.), Refugee News, Refugee Politics (pp. 184-190). Abingdon, UK: Routledge.

Blumler, J. G., \& Coleman, S. (2015). Democracy and the media - revisited. Javnost - The Public, 22(2), 111-128. https://doi.org/10.1 080/13183222.2015.1041226

Bonjour, S., \& Schrover, M. (2015). Public debate and policy-making on family migration in the Netherlands, 1960-1995. Journal of Ethnic and Migration Studies, 41(9), 1475-1494. https://doi.org/10.1080/13691 83X.2015.1021588

Brauck, M., Diez, G., Kühn, A., Müller, M. U., Nezik, A.-K., \& Steinmetz, V. (2016, February 24). Lying press? Germans lose faith in the fourth estate. Spiegel International. Retrieved from https://www.spiegel.de/ international/germany/most-germansthink-the-press-is-lying-to-them-aboutrefugees-a-1079049.html

Bytzek, E. (2005). Kosovokrieg, Kriegsberichterstattung und die Popularität der deutschen Regierungsparteien und -politiker [Kosovo war, war reporting and the popularity of the German governing political parties and politicians]. Medien- und Kommunikationswissenschaft, 53(2-3), 369-388. https://doi.org/10.5771/1615634x-2005-2-3-369

Christians, C. G., Glasser, T. L., McQuail, D., Nordenstreng, K., \&White, R. A. (2009). Normative theories of the media: Journalism in democratic societies. Urbana, IL: University of Illinois Press.

Czymara, C. S., \& Schmidt-Catran, A. W (2017). Refugees unwelcome? Changes in the public acceptance of immigrants and refugees in Germany in the course of Europe's "immigration crisis". European Sociological Review, 33(6), 735-751. https://doi. org/10.1093/esr/jcx071

Dekker, R., \& Scholten, P. (2017). Framing the immigration policy agenda: A qual- 
itative comparative analysis of media effects on Dutch immigration policies. The International Journal of Press/ Politics, 22(2), 202-222. https://doi. org/10.1177/1940161216688323

de Vreese, C. H. (2005). News framing: Theory and typology. Information Design Journals + Document Design, 13(1), 51-62. https://doi.org/10.1075/idjdd.13.1.06vre

Eide, E., \& Ytterstad, A. (2011). The tainted hero: Frames of domestication in Norwegian press representation of the Bali climate summit. The International Journal of Press/Politics, 16(1), 50-74. https://doi. org/10.1177/1940161210383420

Entman, R. M. (1993). Framing: Toward clarification of a fractured paradigm. Journal of Communication, 43(4), 51-58. https://doi. org/10.1111/j.1460-2466.1993.tb01304.x

Entman, R. M. (2004). Projections of power: Framing news, public opinion and U.S. foreign policy. Chicago, IL: University of Chicago Press.

Farnsworth, S. J., \& Lichter, S. R. (2003). The nightly news nightmare: Network television's coverage of U.S. presidential elections, 1988-2000. Lanham, MD: Rowman \& Littlefield.

Gamson, W. A., \& Modigliani, A. (1987). The changing culture of affirmative action. In R. G. Braungart \& M. M. Braungart (Eds.), Research in political sociology (pp. 137-177). Greenwich, CT: JAIPress.

Gamson, W. A., \& Modigliani, A. (1989). Media discourse and public opinion on nuclear power: A constructionist approach. The American Journal of Sociology, 95(1), 1-37. https://doi.org/10.1086/229213

Glazier, R. A., \& Boydstun, A. E. (2012). The president, the press, and the war: A tale of two framing agendas. Political Communication, 29(4), 428-446. https://doi.org/10.1 080/10584609.2012.721870

Greck, R. (2018). Schaffen wir das? Frames im medialen Diskurs zur Flüchtlingskrise in der deutschen Regionalpresse des Jahres 2015 und ihre Lösungsorientierung [Can we do it? Frames in the public debate about the refugee crisis in the German regional press in 2015 and their orientation towards solutions]. Publizistik, 63(3), 359-382. https://doi.org/10.1007/s11616018-0437-x
Greussing, E., \& Boomgaarden, H. G. (2017). Shifting the refugee narrative? An automated frame analysis of Europe's 2015 refugee crisis. Journal of Ethnic and Migration Studies, 43(11), 1749-1774. https:// doi.org/10.1080/1369183X.2017.1282813

Haller, M. (2017). Die «Flüchtlingskrise» in den Medien. Tagesaktueller Journalismus zwischen Meinung und Information [The "migration crisis" in the media. Daily coverage between opinion and information]. OBS-Arbeitsheft 93. Frankfurt am Main, Germany: Otto Brenner Stiftung.

Hayes, D., \& Guardino, M. (2010). Whose views made the news? Media coverage and the march to war in Iraq. Political Communication, 27(1), 59-87. https://doi. org/10.1080/10584600903502615

Helbling, M. (2014). Framing immigration in Western Europe. Journal of Ethnic and Migration Studies, 40(1), 21-41. https:// doi.org/10.1080/1369183X.2013.830888

Hemmelmann, P., \& Wegner, S. (2016). Flüchtlingsdebatte im Spiegel von Medien und Parteien. Ein Überblick [Refugee debate as reflected in the media and political parties. An overview]. Communicatio Socialis, 49(1), 21-38. https://doi. org/10.5771/0010-3497-2016-1-21

Hölig, S., \& Hasebrink, U. (2018). Germany. In N. Newman with R. Fletcher, A. Kalogeropoulos, D. Levy, \& R. Kleis Nielsen (Eds.), Reuters Institute digital news report 2018 (pp. 80-81). Retrieved from https://tinyurl. com/Reuters-Institute2018

Horsti, K. (2007). Asylum seekers in the news: Frames of illegality and control. Observatorio (OBS) Journal, 1(1), 145-161. Retrieved from http://obs.obercom.pt/index. $\mathrm{php} / \mathrm{obs} /$ article/view/45

Ihlen, Ø., \& Thorbjørnsrud, K. (2014). Making news influencing decisions: Three threshold cases concerning forced return of immigrants. European Journal of Communication, 29(2), 139-152. https://doi. org/10.1177/0267323114523149

Juran, S., \& Broer, P. N. (2017). A profile of Germany's refugee population. Population and Development Review, 43(1), 149-157. https://doi.org/10.1111/padr.12042

Klemm, M. (2015). Wenn Politik auf Einspielfilme trifft. Zur multimodalen Argumentation in der politischen Fernsehdiskussion 
Hart aber fair [When politics meets video clips. On multimodal argumentation in the political talk show Hart aber fair]. In H. Girth \& S. Michel (Eds.), Polit-Talkshows. Interdisziplinäre Perspektiven auf ein multimodales Format [Political talk shows. Interdisciplinary perspectives on a multimodal format] (pp. 97-120). Stuttgart, Germany: Ibidem.

Klocker, N., \& Dunn, K. M. (2003). Who's driving the asylum debate? Newspaper and government representations of asylum seekers. Media International Australia, 109(1), 71-92. https://doi. org/10.1177/1329878X0310900109

Krzyżanowski, M., Triandafyllidou, A., \&Wodak, R. (2018). The mediatization and the politicization of the 'refugee crisis' in Europe. Journal of Immigrant \& Refugee Studies, 16(1-2), 1-14. https://doi.org/10.1080/155 62948.2017.1353189

Lengauer, G., Donges, P., \& Plasser, F. (2014). Perceptions of media power in politics. In B. Pfetsch (Ed.), Political communication cultures in Western Europe. Attitudes of political actors and journalists in nine countries (pp. 171-195). Basingstoke, UK: Palgrave Macmillan.

Lichtenstein, D., \& Koerth, K. (2020). Different shows, different stories: How German TV formats challenged the government's framing of the Ukraine crisis. Media, War \& Conflict. Advanced online publication. https://doi. org/10.1177/1750635220909977

Lynch, J., \& McGoldrick, A. (2005). Peace journalism. Stroud, UK: Hawthorn Press.

Maurer, M., Jost, P., Haßler, J., \& Kruschinski, S. (2019). Auf den Spuren der Lügenpresse. Zur Richtigkeit und Ausgewogenheit der Medienberichterstattung in der "Flüchtlingskrise» [On the trail of the "lying press". On the accuracy and balance of media coverage during the "refugee crisis"]. Publizistik, 64(1), 15-35. https://doi. org/10.1007/s11616-018-00466-y

Mayring, P. (2014). Qualitative content analysis. Theoretical foundation, basic procedures and software solution. Klagenfurt, Austria: Beltz.

McClennen, S., \& Maisel, R. (2014). Is satire saving our nation? Mockery and American politics. Basingstoke, UK: Palgrave Macmillan.

McQuail, D. (2010). Mass communication theory. London, UK: Sage.

Meyer, T. (2002). Media democracy: How the media colonize politics. Cambridge, UK: Polity Press.

Mushaben, J. M. (2017). Wir schaffen das! Angela Merkel and the European refugee crisis. German Politics, 26(4), 516-533. https:// doi.org/10.1080/09644008.2017.1366988

Nitsch, C., \& Lichtenstein, D. (2019). Satirizing international crises. The depiction of the Ukraine, Greek debt, and migration crises in political satire. Studies in Communication Sciences, 19(1), 85-103. https://doi. org/10.24434/j.scoms.2019.01.007

Olsson, E.-K., Söderlund, M., \& Falkheimer, J. (2015). Communicating terror: Selecting, reinforcing and matching frames in connection to the attacks in Norway on July 22, 2011. Scandinavian Journal of Public Administration, 19(1), 3-22. Retrieved from https://ojs.ub.gu.se/index.php/sjpa/ article/view/3117

Otto, L., Glogger, I., \& Boukes, M. (2017). The softening of journalistic political communication - A critical review of sensationalism, soft news, infotainment, and tabloidization and a comprehensive framework model. Communication Theory, 27(2), 136-155. https://doi.org/10.1111/ comt.12102

Pries, L. (2020). "We will manage it" - Did chancellor Merkel's dictum increase or even cause the refugee movement in 2015? International Migration, 58(5), 18-28. https://doi.org/10.1111/imig.12684

Reinemann, C., Stanyer, J., Scherr, S., \& Legnante, G. (2012). Hard and soft news: A review of concepts, operationalizations and key findings. Journalism, 13(2), 221-239. https://doi. org/10.1177/ 1464884911427803

Roggeband, C., \& Vliegenthart, R. (2007). Divergent framing: The public debate on migration in the Dutch parliament and media, 1995-2004. West European Politics, 30(3), 524-548. https://doi. org/10.1080/01402380701276352

Simon, A., \& Xenos, M. (2000). Media framing and effective public deliberation. Political 
Communication, 17(4), 363-376. https:// doi.org/10.1080/10584600050178979

Suchman, M. C. (1995). Managing legitimacy: Strategic and institutional approaches. The Academy of Management Review, 20(3), 571-610. https://doi.org/10.5465/ amr.1995.9508080331

Suro, R. (2009). Promoting stalemate: The media and US policy on migration. Washington, DC: Migration Policy Institute. Retrieved from https://tinyurl.com/Suro2009

Thussu, D. K. (2007). News as entertainment: The rise of global entertainment. London, UK: Sage.

Udris, L. (2019). Political communication in and about crises. Potentials of a fragmented field. Studies in Communication Sciences, 19(1), 131-152. https://doi. org/10.24434/j.scoms.2019.01.009

van Gorp, B. (2005). Where is the frame? Victims and intruders in the Belgian press coverage of the asylum issue. European Journal of Communication, 20(4), 484-507. https://doi. org/10.1177/0267323105058253

Vliegenthart, R., \& Roggeband, C. (2007). Framing immigration and integration: Relationships between media and parliament in the Netherlands, 1995-2004. International Communication Gazette, 69(3), 295-319. https://doi. org/10.1177/1748048507076582

Vliegenthart, R., \&Walgrave, S. (2011). When the media matter for politics: Partisan moderators of the mass media's agenda-setting influence on parliaments in Belgium. Party Politics, 17(3), 321-342. https://doi. org/10.1177/1354068810366016
Vollmer, B., \& Karakayali, S. (2018). The volatility of the discourse on refugees in Germany. Journal of Immigrant \& Refugee Studies, 16(1-2), 118-139. https://doi.org/ 10.1080/15562948.2017.1288284

Vukov, T. (2003). Imagining communities through immigration policies: Governmental regulation, media spectacles and the affective politics of national borders. International Journal of Cultural Studies, 6(3), 335-353. https://doi. org/10.1177/13678779030063006

Walgrave, S., Soroka, S., \& Nuytemans, M. (2008). The mass media's political agenda-setting power a longitudinal analysis of media, parliament, and government in Belgium (1993 to 2000). Comparative Political Studies, 41(6), 814-836. https:// doi.org/10.1177/0010414006299098

Walgrave, S., \& van Aelst, P. (2006). The contingency of the mass media's political agenda-setting power: Towards a preliminary theory. Journal of Communication, 56(1), 88-109. https://doi.org/10.1111/ j.1460-2466.2006.00005.x

Wessler, H. (2018). Habermas and the media. Cambridge, UK: Polity Press.

Wolfe, M., Jones, B. D., \& Baumgartner, F. R. (2013). A failure to communicate: Agendasetting in media and policy studies. Political Communication, 30(2), 175-192. https://doi.org/10.1080/10584609.2012.7 37419

Zaller, J. (2003). A new standard of news quality: Burglar alarms for the monitorial citizen. Political Communication, 20(2), 109-130. https://doi. org/10.1080/10584600390211136 


\section{Appendix}

Table A1: Media material under study

\begin{tabular}{|c|c|c|c|}
\hline & Reach (in millions) & Market share (in \%) & Channel \\
\hline \multicolumn{4}{|l|}{ Newscast } \\
\hline Tagesschau, 8 p.m. & 4.99 & 17.9 & Das Erste \\
\hline \multicolumn{4}{|l|}{ Talk shows } \\
\hline Anne Will & 1.47 & 10.2 & Das Erste \\
\hline Maybrit IIIner & 2.49 & 12.1 & ZDF \\
\hline \multicolumn{4}{|l|}{ Satirical shows } \\
\hline heute-show & 3.46 & 14.4 & ZDF \\
\hline Die Anstalt & 2.29 & 11.4 & ZDF \\
\hline Neo Magazin Royale & 0.12 & 1.4 & ZDF \\
\hline
\end{tabular}

Note: Numbers refer to the year 2015 (source: www.quotenmeter.de). For Neo Magazin Royale, the numbers were available only for the period of January to June 2015; Neo Magazine Royale reaches only a small audience via TV but is highly viewed via the online ZDF Mediathek. 